\title{
Qualitative characteristics of company annual reports as perceived by constituencies in the reporting environment
}

\author{
D.K. Flynn \\ Department of Accounting, University of Cape Town, Rondebosch
}

In this article a list of qualitative characteristics which investors and analysts are likely to require from the annual report of a listed company is identified. The research analyses data obtained from a questionnaire in an effort to determine which qualitative characteristics are most important to investors and financial analysts. It is attempted to determine whether a more parsimonious list can be constructed. Finally, a statistical test is performed in order to establish whether preparers and regulators of financial information perceive the qualitative characteristics deemed important by investors and analysts correctly.

S. Afr. J. Bus. Mgmt. 1985, 16: 119-124

In hierdie artikel word 'n lys van kwalitatiewe eienskappe wat beleggers en finansiële analiseerders moontlik van die jaarverslag van 'n gekwoteerde maatskappy kan verwag, geïdentifiseer. Die navorsing analiseer data verkry van ' $n$ vraelys in 'n poging om te bepaal watter kwalitatiewe eienskappe die mees belangrikste vir beleggers en analiseerders is. Daar word verder gepoog om vas te stel of 'n korter lys opgestel kan word. Laastens word 'n statistiese toets uitgevoer om te bepaal of die voorbereiders en reguleerders van finansiële inligting die kwalitatiewe eienskappe wat beleggers en analiseerders belangrik ag, korrek waarneem.

S.Afr. Tydskr. Bedryfsl. 1985, 16: 119-124
D.K. Fynn

Department of Accounting, University of Cape Town,

Private Bag, Rondebosch, 7700 Republic of South Africa

\section{Introduction}

The annual report of a listed company which includes the annual financial statements is one source of information for investors. The information provided in the annual report is used by investors as an input into their investment decision model. When preparing the annual report, the objective of providing useful information must be translated into accounting practices. A set of criteria is necessary to assess the quality of information provided and the usefulness of the information to the users. The set of criteria is generally referred to in the accounting literature as the qualitative characteristics of information. Establishing such a set of criteria is in itself a problem. A more complex problem, however, is determining the relative importance of each criterion to the users.

This study dealt with the perceptions of the three major constituencies in the financial reporting environment in South Africa with regard to the criteria necessary for an annual report to be a useful source of information. In addition, it was aimed to test whether the criteria used are perceived similarly by each group. The three constituencies identified were the companies who supply the information, the investors who create the demand for the information, and the regulatory bodies who attempt to ensure equity and efficiency in the resulting market for information. For the purpose of the study, the investor constituency was divided into three groups: Individual investors, institutional investors, and financial analysts. The regulatory constituency comprises the Accounting Practices Committee (APC) and the Accounting Practices Board (APB).

The study of qualitative characteristics formed part of a larger research project dealing with various aspects of the financial information environment in South Africa. The part of the study reported in this article had as an objective the testing of the following hypothesis:

$\mathrm{H}_{\mathrm{o}}$ : 'There are no significant differences among the constituencies in the financial reporting environment with regard to perceived criteria for assessment of the usefulness of various accounting practices and resultant disclosure in the annual report of listed companies'.

As background, the establishment of criteria and the issues involved in selecting the criteria against which the usefulness of the annual report can be measured are discussed. It is necessary to bear in mind that these criteria would need to apply to all media used for communicating financial information. With this study, however, attention is focussed specifically on the annual report of listed companies. 


\section{Qualitative characteristics}

A number of alternative lists of qualitative characteristics have been developed by various committees and research studies. Their findings as to a suitable list are summarized in Table 1. For this study a recent list established by the Financial Accounting Standards Board (FASB) in its Statement of Accounting Concepts, Number 2 (SFAC2) was selected. In this Statement it is noted that the need for a conceptual framework for financial accounting and reporting, beginning with consideration of the objectives of financial reporting, is generally recognized (Stamp, 1982). In order to meet this need the FASB took the lead internationally. SFAC2 is the second of a number of proposed publications designed to serve as a constitution, aimed at giving explicit guidance regarding what is appropriate in preparing financial statements.

In its summary of principal conclusions SFAC2 noted that the characteristics of information that make it a desirable commodity can be perceived as a hierarchy of qualities, (Finan-

Table 1 Alphabetical list of qualitative characteristics identified by recent studies

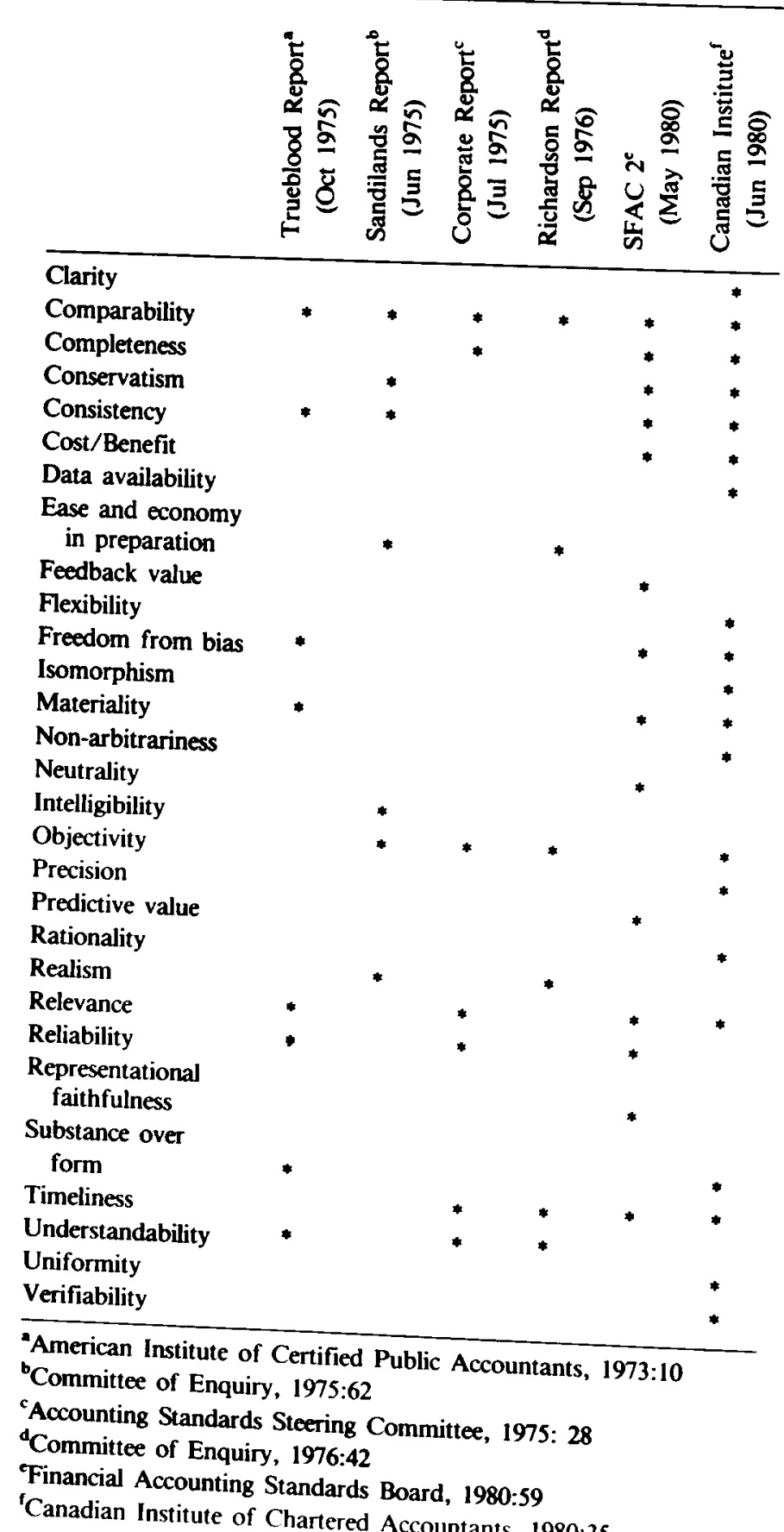

cial Accounting Standards Board, 1980:ix). This hierarchy i displayed in Figure 1 (Financial Accounting Standards Board 1980:15). All the criteria discussed in the Statement do no appear on the hierarchy and no definitive list of criteria wa categorically stated. However, the glossary of terms, defining characteristics provided by SFAC2 (p.xv) was used in thi study as it contained the most comprehensive list of qualitative characteristics (Appendix 1).

SAFC2 concluded that relevance and reliability are the twc primary qualities required from accounting information. Cost and materiality are considered to be the two constraints on the primary qualities. The list of qualities consists of those to be sought when accounting choices are made. The choices are made at two levels in particular. Regulating agencies, such as those responsible for statute, the JSE and the APB in the South African context, who have the power to prescribe reporting practice, make choices at one level. At another level, companies who generate and supply the information also face alternatives and as a result would benefit from a set of criteria against which to judge the quality of their information and guidance in choosing between alternative ways of representing economic events.

It is noteworthy that SFAC2 does not claim to have universal application. Even if the list of criteria was agreed upon, it is not expected that the criteria will always produce consensus on a preferred choice of accounting method. 'Consequently, those who must choose among alternatives are forced to fall back on human judgement to evaluate the relative merits of competing methods' (Financial Accounting Standards Board, 1980:11).

The constraint of materiality receives some attention in SFAC2. The views expressed are highly relevant to the central thought in this study, namely the distinction between objective reality and subjective perception. O'Connor and Collins state that 'an observed association between extant security prices and reported accounting data (or changes therein) provides prima facie evidence as to the informational content of accounting numbers' (O'Connor \& Collins, 1974:70). The implication is that an item disclosed only qualifies as information if there is an observed impact on security prices. The point is then made, however, that this test of informational value is ex poste, whereas suppliers of information have to make judgements as to its materiality before the event.

\section{Methodology}

The data for the research were acquired through a questionnaire mailed to a random sample of 200 listed industrial companies, 85 institutional investors comprising pension funds, insurance companies and banks, and 125 individual investors, whose names were randomly selected from the most recent dividend list of five listed industrial companies. In addition, $\mathbf{3 1 0}$ questionnaires were mailed to the Investment Analyst Society of South Africa as well as to the 18 members of the APC and the 38 members and alternate members of the APB. A covering letter explained the nature of the study and stated that anonymity would be maintained. Detailed instructions were provided with the questionnaire as well as the glossary of terms to assist respondents in understanding the semantics of each of the qualitative characteristics.

Final usable response rates for the research were: Company financial managers - $37 \%$ (74 replies); individual investors $-36 \%$ ( 45 replies); institutional investors - $40 \%$ (34 replies); financial analysts $-29 \%$ (91 replies); the APC $-67 \%$ (12 replies); and the APB $-47 \%$ (18 replies). 


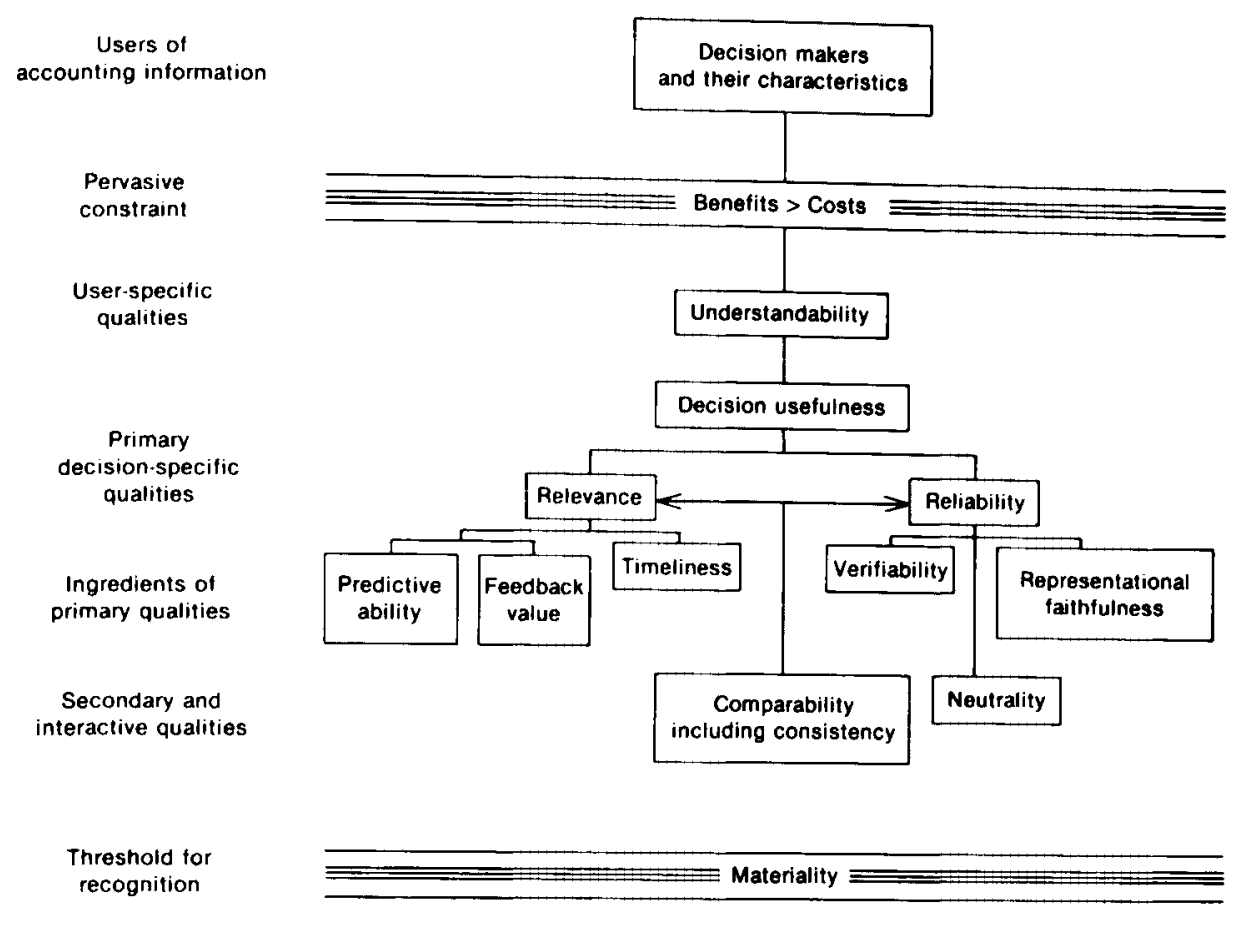

Figure 1 A hierarchy of accounting qualities

various accounting practices do you think are important?' was posed to the three user groups, individual investors, institutional investors and financial analysts. In order to test the hypothesis, a similar question 'What criteria for assessing the usefulness of various accounting practices do you consider to be applied by investors generally?' was posed to company financial managers and accounting regulators. The list of 16 qualitative criteria was provided and respondents were requested to rank the importance of each criterion on a ninepoint scale of importance with one indicating that the item is not considered to be important and nine indicating that it is considered to be very important. In all cases the question was preceded by a short paragraph stressing that the context was only in terms of the annual report. Reference was also made to the glossary of terms which appeared in an Appendix to the questionnaire.

The Statistical Package for the Social Sciences (SPSS), a system of computer programs, was used to manipulate and analyse the data. Three subprograms were used for analysis.

\section{Subprogram CONDESCRIPTIVE}

This subprogram computed descriptive statistics. The mean, standard error, standard deviation, variance, kurtosis, and skewness were requested as options. Only the means have been incorporated in the tables provided, as the standard deviations and other descriptive statistics did not exhibit any notable signs of being unusual.

\section{Subprogram FACTOR}

Factor analysis is essentially a data-reducing technique. It served to identify whether there were relationships between the qualitative characteristics which may have made it possible to reduce the list to a smaller set of principal components or factors.

\section{Subprogram DISCRIMINANT}

This subprogram performed discriminant analysis using two basic methods, directly entering all discriminating variables or by selecting the best discriminating variables first and then proceeding in stepwise fashion. The objective of discriminant analysis is to distinguish statistically between two or more groups of cases. This is achieved through selecting discriminating variables which measure the characteristics on which the groups are expected to differ. A major objective of this study was to seek variables on which the perceptions of the constituencies in the reporting environment differed.

Some bias may be present resulting from sample selection, sample size and non-response. This possible bias may not be trivial. The findings are, however, considered to be exploratory and it is hoped that further research will be undertaken in this area.

\section{Results}

Establishing a list of qualitative characteristics

The mean scores and rankings of the importance of each of the qualitative characteristics as rated by the five constituencies in terms of the question posed to them appear in Table 2. Factor analysis was applied as a data-reducing technique. Factor analysis was used as it was apparent that the list of criteria was becoming longer with more recent studies. While this may reflect an increasing sophistication, it has the detracting effect of becoming cumbersome. Certainly from a purely semantic viewpoint it is difficult to distinguish between freedom from bias and representational faithfulness.

The first factor accounted for $41,7 \%$ of the variance. Thereafter each of the following factors contributed relatively less to the cumulative variance, six factors accounting for a total of $71,6 \%$ of the variance. Using the factor matrix of principal factors plotted in a series of two-dimensional territorial graphs, groupings of characteristics were evident. An interpretation of these groupings is displayed in Table 3. Similar groupings were obtained using a Basic program and cluster analysis in order to group the variables.

Factor analysis does not indicate relative importance of items, but merely serves to identify factors which require their own interpretation within the context of the data. The results obtained are therefore not easily open to interpretation which is not highly subjective. There is however some indication of the similarity of criteria within a group which signifies that a reduction in the number of criteria may be possible if a 


\begin{tabular}{|c|c|c|c|c|c|c|c|c|c|c|c|c|c|c|c|c|}
\hline & 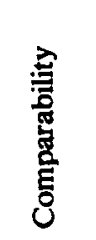 & 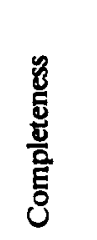 & 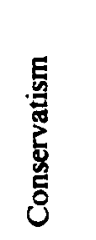 & 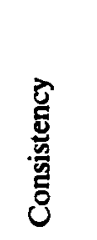 & 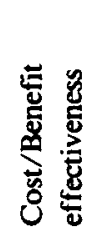 & 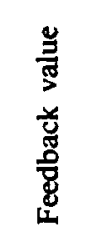 & 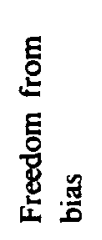 & 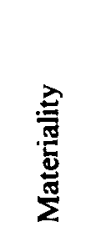 & 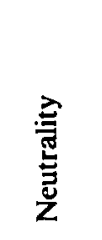 & 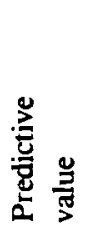 & 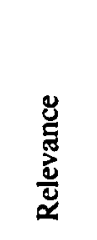 & 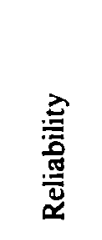 & 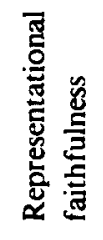 & $\underset{\mathscr{E}}{\mathscr{E}}$ & 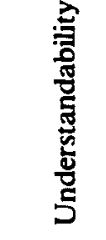 & 窎 \\
\hline $\begin{array}{l}\text { Responding } \\
\text { constituency }\end{array}$ & $\begin{array}{l}\text { Mean } \\
\text { (Rank) }\end{array}$ & $\begin{array}{l}\text { Mean } \\
\text { (Rank) }\end{array}$ & $\begin{array}{l}\text { Mean } \\
\text { (Rank) }\end{array}$ & $\begin{array}{l}\text { Mean } \\
\text { (Rank) }\end{array}$ & $\begin{array}{l}\text { Mean } \\
\text { (Rank) }\end{array}$ & $\begin{array}{l}\text { Mean } \\
\text { (Rank) }\end{array}$ & $\begin{array}{c}\text { Mean } \\
\text { (Rank) }\end{array}$ & $\begin{array}{l}\text { Mean } \\
\text { (Rank) }\end{array}$ & $\begin{array}{l}\text { Mean } \\
\text { (Rank) }\end{array}$ & $\begin{array}{l}\text { Mean } \\
\text { (Rank) }\end{array}$ & $\begin{array}{l}\text { Mean } \\
\text { (Rank) }\end{array}$ & $\begin{array}{l}\text { Mean } \\
\text { (Rank) }\end{array}$ & $\begin{array}{c}\text { Mean } \\
\text { (Rank) }\end{array}$ & $\begin{array}{c}\text { Mean } \\
\text { (Rank) }\end{array}$ & $\begin{array}{l}\text { Mean } \\
\text { (Rank)( }\end{array}$ & \\
\hline $\begin{array}{l}\text { Individual } \\
\text { investors }\end{array}$ & $\begin{array}{l}6,22 \\
(11)\end{array}$ & $\begin{array}{l}7,12 \\
(3)\end{array}$ & $\begin{array}{l}5,95 \\
(13)\end{array}$ & $\begin{array}{c}6,63 \\
(8)\end{array}$ & $\begin{array}{l}5,15 \\
(16)\end{array}$ & $\begin{array}{l}5,71 \\
(14)\end{array}$ & $\begin{array}{l}6,29 \\
(10)\end{array}$ & $\begin{array}{l}6,85 \\
\left(6^{*}\right)\end{array}$ & $\begin{array}{l}5,68 \\
(15)\end{array}$ & $\begin{array}{l}6,02 \\
(11)\end{array}$ & $\begin{array}{l}6,59 \\
(9)\end{array}$ & $\begin{array}{c}7,80 \\
(1)\end{array}$ & $\begin{array}{c}7,05 \\
(5)\end{array}$ & $\begin{array}{c}7,41 \\
(4)\end{array}$ & $\begin{array}{l}7,78 \\
(2)\end{array}$ & $\begin{array}{l}6,85 \\
\left(6^{*}\right)\end{array}$ \\
\hline $\begin{array}{l}\text { Institutional } \\
\text { investors }\end{array}$ & $\begin{array}{l}7,60 \\
(6)\end{array}$ & $\begin{array}{l}7,90 \\
(2)\end{array}$ & $\begin{array}{l}6,13 \\
(15)\end{array}$ & $\begin{array}{c}7,80 \\
(3)\end{array}$ & $\begin{array}{l}5,50 \\
(16)\end{array}$ & $\begin{array}{l}6,67 \\
(13)\end{array}$ & $\begin{array}{l}7,17 \\
\left(9^{*}\right)\end{array}$ & $\begin{array}{l}7,17 \\
\left(9^{*}\right)\end{array}$ & $\begin{array}{l}6,23 \\
(14)\end{array}$ & $\begin{array}{l}7,47 \\
\left(7^{*}\right)\end{array}$ & $\begin{array}{l}7,47 \\
\left(7^{*}\right)\end{array}$ & $\begin{array}{l}7,97 \\
(1)\end{array}$ & $\begin{array}{l}7,13 \\
(11)\end{array}$ & $\begin{array}{l}7,67 \\
\left(4^{*}\right)\end{array}$ & $\begin{array}{l}7,67 \\
\left(4^{*}\right)\end{array}$ & $\begin{array}{l}7,03 \\
(12)\end{array}$ \\
\hline $\begin{array}{l}\text { Financial } \\
\text { analysts }\end{array}$ & $\begin{array}{l}7,60 \\
(3)\end{array}$ & $\begin{array}{l}7,67 \\
(2)\end{array}$ & $\begin{array}{l}5,67 \\
(15)\end{array}$ & $\begin{array}{c}7,38 \\
(5)\end{array}$ & $\begin{array}{l}5,47 \\
(16)\end{array}$ & $\begin{array}{l}6,32 \\
(13)\end{array}$ & $\begin{array}{l}6,43 \\
(12)\end{array}$ & $\begin{array}{l}7,00 \\
(10)\end{array}$ & $\begin{array}{l}5,92 \\
(14)\end{array}$ & $\begin{array}{l}7,43 \\
(4)\end{array}$ & $\begin{array}{l}7,26 \\
(7)\end{array}$ & $\begin{array}{c}8,02 \\
\text { (1) }\end{array}$ & $\begin{array}{l}7,12 \\
(9)\end{array}$ & $\begin{array}{l}7,24 \\
(8)\end{array}$ & $\begin{array}{l}7,32 \\
(6)\end{array}$ & (11) \\
\hline $\begin{array}{l}\text { Company } \\
\text { management }\end{array}$ & $\begin{array}{l}7, \infty 0 \\
\left(6^{*}\right)\end{array}$ & $\begin{array}{l}6,85 \\
(8)\end{array}$ & $\begin{array}{l}5,96 \\
(14)\end{array}$ & $\begin{array}{l}7,39 \\
(3)\end{array}$ & $\begin{array}{l}5,32 \\
(16)\end{array}$ & $\begin{array}{l}6,05 \\
(13)\end{array}$ & $\begin{array}{l}6,40 \\
\text { (11) }\end{array}$ & $\begin{array}{l}7,30 \\
(4)\end{array}$ & $\begin{array}{l}5,88 \\
(15)\end{array}$ & $\begin{array}{l}6,82 \\
(9)\end{array}$ & $\begin{array}{l}7,00 \\
\left(6^{*}\right)\end{array}$ & $\begin{array}{l}7,68 \\
\text { (1) }\end{array}$ & $\begin{array}{l}6,72 \\
(10)\end{array}$ & $\begin{array}{l}7,03 \\
(5)\end{array}$ & $\begin{array}{l}7,60 \\
(2)\end{array}$ & $\begin{array}{l}6,22 \\
(12)\end{array}$ \\
\hline Regulators & $\begin{array}{l}7,04 \\
(9)\end{array}$ & $\begin{array}{l}7,35 \\
\left(4^{*}\right)\end{array}$ & $\begin{array}{l}5,38 \\
(14)\end{array}$ & $\begin{array}{l}7,12 \\
(7)\end{array}$ & $\begin{array}{l}4,31 \\
(16)\end{array}$ & $\begin{array}{l}5,50 \\
(13)\end{array}$ & $\begin{array}{l}6,47 \\
(11)\end{array}$ & $\begin{array}{l}6,96 \\
(10)\end{array}$ & $\begin{array}{l}6,23 \\
(12)\end{array}$ & $\begin{array}{l}7,23 \\
(6)\end{array}$ & $\begin{array}{l}7,35 \\
\left(4^{*}\right)\end{array}$ & $\begin{array}{l}8,15 \\
\text { (1) }\end{array}$ & $\begin{array}{l}7,08 \\
(8)\end{array}$ & $\begin{array}{l}7,50 \\
(3)\end{array}$ & $\begin{array}{l}7,58 \\
(2)\end{array}$ & $\begin{array}{l}5,35 \\
(15)\end{array}$ \\
\hline
\end{tabular}

Scale: Most important $=9$; Least important $=1$

*Equal ranking

Table 3 Grouping of qualitative characteristics on territorial map

\begin{tabular}{ll}
\hline Group & \multicolumn{1}{c}{ Characteristic } \\
\hline 1 & $\begin{array}{l}\text { Feedback value } \\
\text { Freedom from bias } \\
\text { Neutrality } \\
\text { Materiality } \\
\text { Reliability } \\
\text { Representational faithfulness } \\
\end{array}$ \\
Conservatism \\
Cost/Benefit effectiveness \\
Comparability \\
4 & $\begin{array}{l}\text { Completeness } \\
\text { Consistency } \\
\text { Predictive value } \\
\text { Relevance }\end{array}$ \\
6 & Timeliness \\
& Understandability \\
& Verifiability \\
\hline
\end{tabular}

more embracing term could be found to capture the full meaning of the criterion.

A study by Joyce, Libby \& Sunder (1982) examined a similar aspect of the criterion list. Their fundamental assumption was that if the qualitative characteristics could be identified and defined, they would help standard setters in selecting financial accounting methods. They further identified three necessary conditions for the list of qualitative characteristics to facilitate standard setting. These conditions are, firstly, that the qualitative characteristics should be operational, secondly, that they should be comprehensive, and thirdly, that there should be a minimum amount of overlap in meaning. The third condition, referred to as discriminant validity, if not present, would suggest that a set of fewer qualitative characteristics would be equally acceptable.
The study used former members of the American Accounting Practices Committee and of the FASB. The study was conducted under rigorous experimental and statistical conditions, using a multitrait-multimethod matrix. They concluded that 'while the qualitative characteristics appear to constitute a comprehensive set of attributes for accounting policy choices, the set is not parsimonious' (Joyce, et al., 1982:655). A further test, aimed at establishing a smaller set of qualitative characteristics, was applied. It was evident, using a 'predictive-ability test', that if only the five most important characteristics (relevance, reliability, understandibility, representational faithfulness, and comparability) were retained, virtually no further change in predictive-ability resulted. It may be of some significance that four of the five characteristics were in different groups identified in this study using factor analysis as in Table 3.

A study using the British Accounting Standards Committee was conducted by Stamp (1982:126). Each member was asked to rank the $\mathbf{2 0}$ criteria (see Table 1). The relative rankings of the two studies cited are listed in Table 4 for comparison with this study. The weighted group mean of the criterion is used for ranking in this study and only the first ten qualitative characteristics considered to be important are cited in rank order of importance.

\section{Qualitative characteristics as perceived by the constituencies}

The results of the question relating to qualitative characteristics summarized in terms of mean scores and ranking in Table 2 were further processed using discriminant analysis. One discriminating function at the 0,01 level of significance emerged.

Three significant variables in the discriminant function, namely comparability, predictive ability, and understandibility were identified from the loadings, using the direct method option. As there was a total of 16 variables, and discrimination was being sought between five groups, the results were subjected to further statistical analysis. The stepwise option of 
Table 4 Relative ranking of qualitative characteristics compared with two research studies

\begin{tabular}{|c|c|c|c|}
\hline Rank & This study & $\begin{array}{l}\text { Stamp, } 1982 \\
\text { (U.K.) }\end{array}$ & $\begin{array}{l}\text { Joyce, et al., } \\
1982 \text { (U.S.) }\end{array}$ \\
\hline 1 & Reljability & Relevance & Relevance \\
\hline 2 & Understandability & Clarity & Reliability \\
\hline 3 & Completeness & $\begin{array}{l}\text { Substance over } \\
\text { form }\end{array}$ & Understandability \\
\hline 4 & Timeliness & Timeliness & $\begin{array}{l}\text { Representational } \\
\text { faithfulness }\end{array}$ \\
\hline 5 & Consistency & Comparability & Comparability \\
\hline 6 & Comparability & Materiality & Neutrality \\
\hline 7 & Relevance & $\begin{array}{l}\text { Freedom from } \\
\text { bias }\end{array}$ & Verifiability \\
\hline 8 & Predictive ability & Objectivity & Predictive value \\
\hline 9 & Materiality & Rationality & Timeliness \\
\hline 10 & $\begin{array}{l}\text { Representational } \\
\text { faithfulness }\end{array}$ & Full disclosure & Feedback value \\
\hline
\end{tabular}

processing was adopted to identify the most significant variables in order of their impact on the linear discriminant function. The first four variables, identified in order of importance, were comparability, verifiability, predictive value, and understandibility. The inclusion at an early stage in the stepwise procedure of verifiability, which was not heavily weighted in the first discriminant function, results from its dominance as a second discriminant function, which was, however, not significant at the 0,01 level.

Rankings may be used in order to improve interpretation of 'Comparability' as the most significant discriminating variable. Analysts view this quality as the third most important criterion whereas all other constituencies view it as less important, with individual investors relegating it to 11 th position.

Using the mean scores as an indicator of the specific groups among which there may be significant differences, three further discriminant tests were performed. Individual investors were compared with institutional investors, but no significant discriminating function was apparent. However, when analysts, the third user group, were included a discriminant function was evident at the 0,01 level of significance. The function weighed heavily on comparability and predictive value. The differences are again apparent when consulting Table 2. Finally company management was compared with regulators and no significant discriminant function was apparent.

\section{Implications for annual reports}

The findings of this study differed from the two recent overseas studies previously referred to (Stamp, 1982 and Joyce, et al., 1982), in that relevance was found to be the most important qualitative characteristic in both overseas studies. Reliability, however, was consistently the most important criterion perceived by all three user groups and the other two constituencies perceived correctly that this would be so. This study differs from the other two studies in that it focussed specifically on the annual report, whereas the other studies focussed on the all-embracing concept of accounting information.

These findings tend to indicate that investors actually view the annual report as a confirmatory source of information, validating information received from other sources on which they may already have reacted. The view that 'information may confirm expectations or it may change them' (Financial Accounting Standards Board, 1980:21) implies that if the quality of reducing uncertainty is present, an item qualifies as information of use. This further implies that although uncertainty may be reduced, the decision may not be altered.

Particularly noteworthy is the suggestion in SFAC2 that 'there seems to be considerable support for the view that reliability should be the dominant quality in the information conveyed in financial statements, even at the expense of relevance, while the opposite is true of information conveyed by means outside of financial statements' (Financial Accounting Standards Board, 1980:19). The findings of this study indicate that this perception is held by all constituencies in the financial reporting environment.

\section{References}

Accounting Standards Steering Committee. July 1975. The Corporate Report. Institute of Chartered Accountants in England Wales, p.28.

American Institute of Certified Public Accountants. October 1973. Report of the Study Group on Objectives of Financial Statements. New York: Chaiman R. Trueblood, p.10.

Canadian Institute of Chartered Accountants. June 1980. Corporate Reporting: Its Future Evolution. Toronto: Chairman E. Stamp, p.35.

Committee of Enquiry, Chancellor of the Exchequer. June 1975. Report of the Inflation Committee. London: Chairman F.E.P. Sandilands, p.62.

Committee of Enquiry, presented to the House of Representatives. September 1976. Commission of Inquiry into Inflation Accounting. Chairman I.L.M. Richardson, p.42.

Financial Accounting Standards Board. May 1980. Statement of Financial Accounting Concepts Number 2, Qualitative Characteristics of Accounting Information. Stamford, Connecticut, pp.(ix), (xv), 4, 15, 19, 21.

Joyce, J., Libby, R. \& Sunder, S. 1982. Using the FASB's Qualitative Characteristics in Accounting Policy Choices. J. Accounting Res., vol. 20, 654-675.

O'Connor, M.C. \& Collins, D.W. 1974. Towards Establishing User Oriented Materiality Standards. J. Account., December, p.70.

Stamp, E. 1982. First Steps toward a British Conceptual Framework. Account., March, pp.123, 126.

\section{Appendix 1}

A. Comparability:

The quality of information that enables the user to identify similarities in, and differences between, two sets of economic phenomena.

B. Completeness:

The inclusion in reported information of everything material that is necessary for faithful representation of the relevant phenomena.

C. Conservatism:

A prudent reaction to uncertainty to try to ensure that uncertainty and risks inherent in business situations are considered adequately.

D. Consistency:

Conformity from period to period with unchanging policies and procedures.

E. Cost/Benefit effectiveness:

The weighing of benefits against costs in order to make possible a choice among alternatives that will yield the maximum benefit at the least cost. Note that the chief benefits are usually to the users, while most of the costs are borne by management. The criteria therefore require a value judgement based on costs and benefits to society as a whole.)

F. Feedback value:

The quality of information that enables users to confirm or correct prior expectations.

G. Freedom from bias:

Bias in measurement is the tendency of a measure to fall on one side more often than on the other of what it represents instead of being equally likely to fall on either side. Bias in acoounting measures means a tendency to be consistently too high or too low.

H. Materiality:

The magnitude of an omission or misstatement of accounting information that, in the light of surrounding circumstances, makes it probable that the judgement of a reasonable person relying on 
the information would have been changed or influenced by the omission or misstatement.

I. Neutrality:

Absence in reported information of bias intended to attain a predetermined result or to induce a particular mode of behaviour.

J. Predictive value:

The quality of information that helps users to increase the likelihood of forecasting the outcome of past or present events correctly.

K. Relevance:

The capacity of information to make a difference in a decision by helping users to form predictions about the outcomes of past, present and future events or to confirm or correct prior expectations.

L. Reliability:

The quality of information that assures that information is reasonably free from error and bias and faithfully represents what it purports to represent.

M. Representational faithfulness:

Correspondence or agreement between a measure or description and the phenomenon that it purports to represent (sometimes called validity).

N. Timeliness:

Having information available to a decision maker before it loses its capacity to influence decisions.

O. Understandability:

The quality of information that enables users to perceive its significance.

P. Verifiability:

The ability among measurers to ensure through consensus that information represents what it purports to represent or that the chosen method of measurement has been used without error or bias. 